*alls View/Frint Document Cover Sheet tose

This document was retrieved from the Boeing ISEARCH System.

Accession \#: D196069821

Document \#: SD-WM-TP-307

Title/Desc:

TANK 241C204 TANK CHARACTERIZATION PLAN 


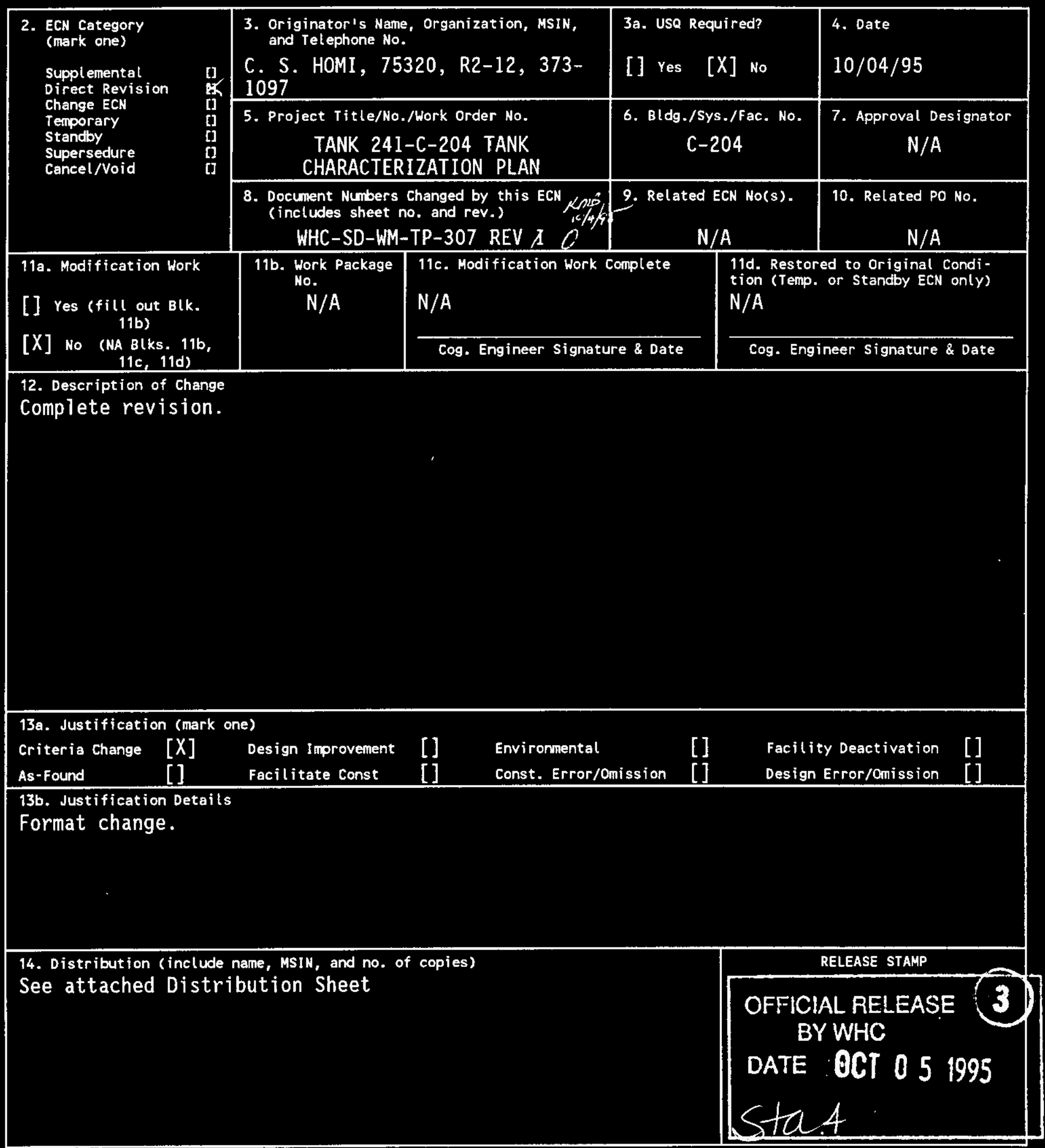




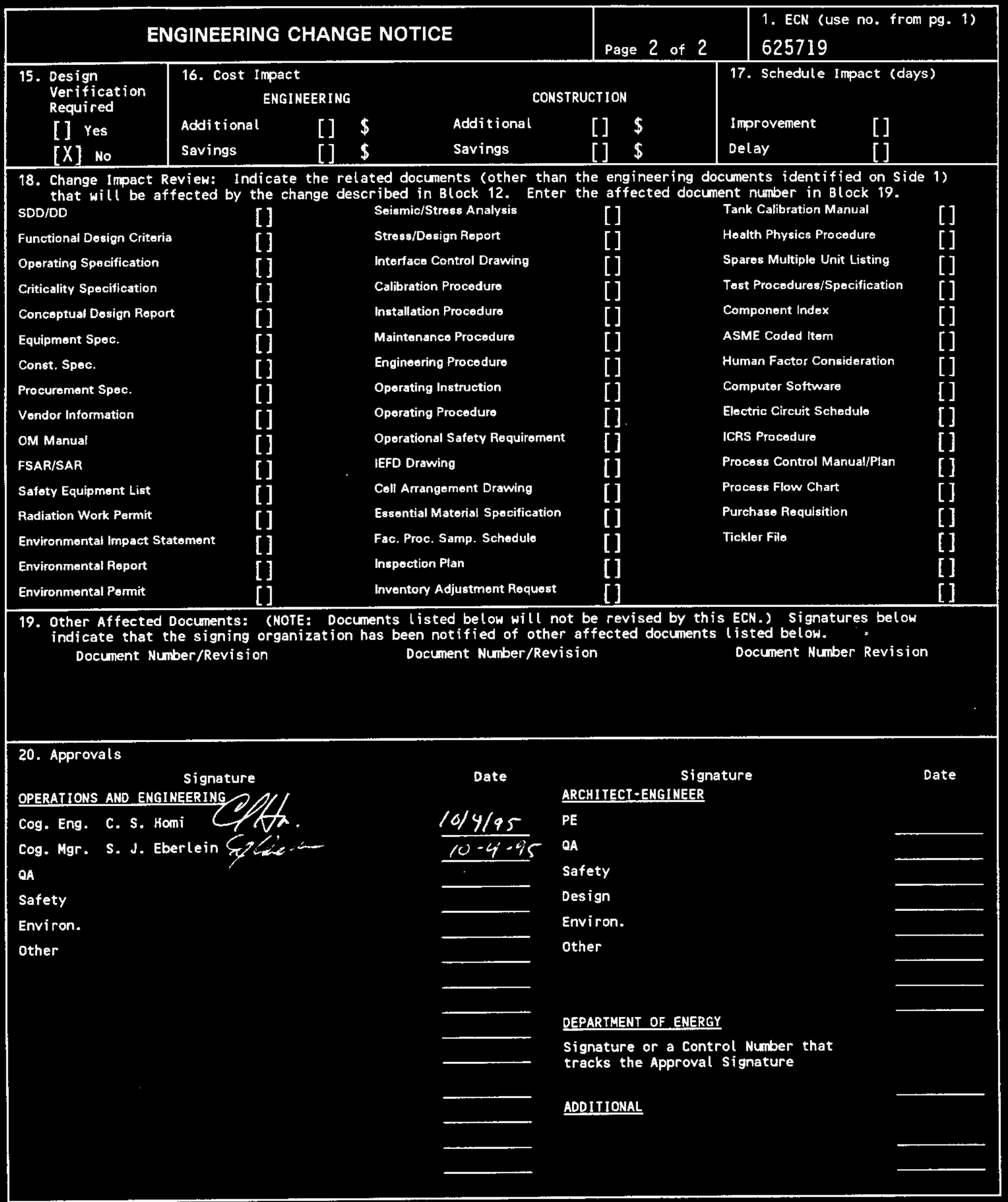




\section{RELEASE AUTHORIZATION}

Document Number: WHC-SD-WM-TP-307, REV 1

Document Title: Tank 241-C-204 Tank Characterization Plan

Release Date: $\quad 10 / 4 / 95$

This document was reviewed following the procedures described in WHC-CM-3-4 and is:

APPROVED FOR PUBLIC RELEASE

WHC Information Release Administration Specialist:
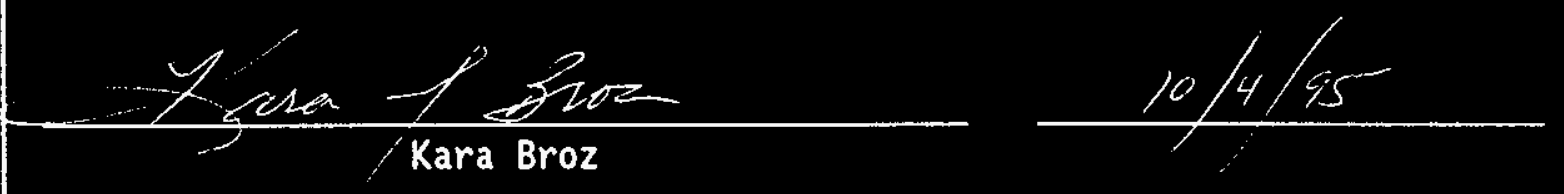

TRADEMARK DISCLAIMER. Reference herein to any specific commercial product, process, or service by trade name, trademark, manufacturer, or otherwise, does not necessarily constitute or imply its endorsement, recommendation, or favoring by the United States Government or any agency thereof or its contractors or subcontractors.

This report has been reproduced from the best available copy. Available in paper copy. Printed in the United States of America. To obtain copies of this report, contact:

Westinghouse Hanford Company - Document Control Services

P.0. Box 1970, Mailstop H6-08, Richland, WA 99352

Telephone: (509) 372-2420; Fax: (509) 376-4989 
2. Title

TANK 241-C-204 TANK CHARACTERIZATION PLAN

5. Key Words

CHARACTERIZATION, GENERAL SAFETY ISSUES, SPECIFIC SAFETY ISSUES, INFORMATION REQUIREMENTS, PRIORITY

3. Number WHC-SD-WM-TP-307

6. Author

Name:

signature

Organization/Charge Code

\section{Abstract}

This document is a plan that identifies the information needed to address relevant issues concerning short-term and long-term safe storage and long-term management of Single-Shel1 Tank (SST) 241-C-204.

OFFICIAL FELEASE BY WHIC 1 
(2) Title

TANK 241-C-204 TANK CHARACTERIZATION PLAN

CHANGE CONTROL RECORD

(3) Revision (4) Description of Change - Replace, Add, and Delete Pages

\begin{tabular}{l|ll}
0 & (7) WHC-SD-WM-TP-307 REV. 0, EDT 610031,
\end{tabular} March 6, 1995

1 RS Complete revision to new format, ECN 625719

Authorized for Release

(5) Cog. Engr. (6) Cog. Mgr. Date

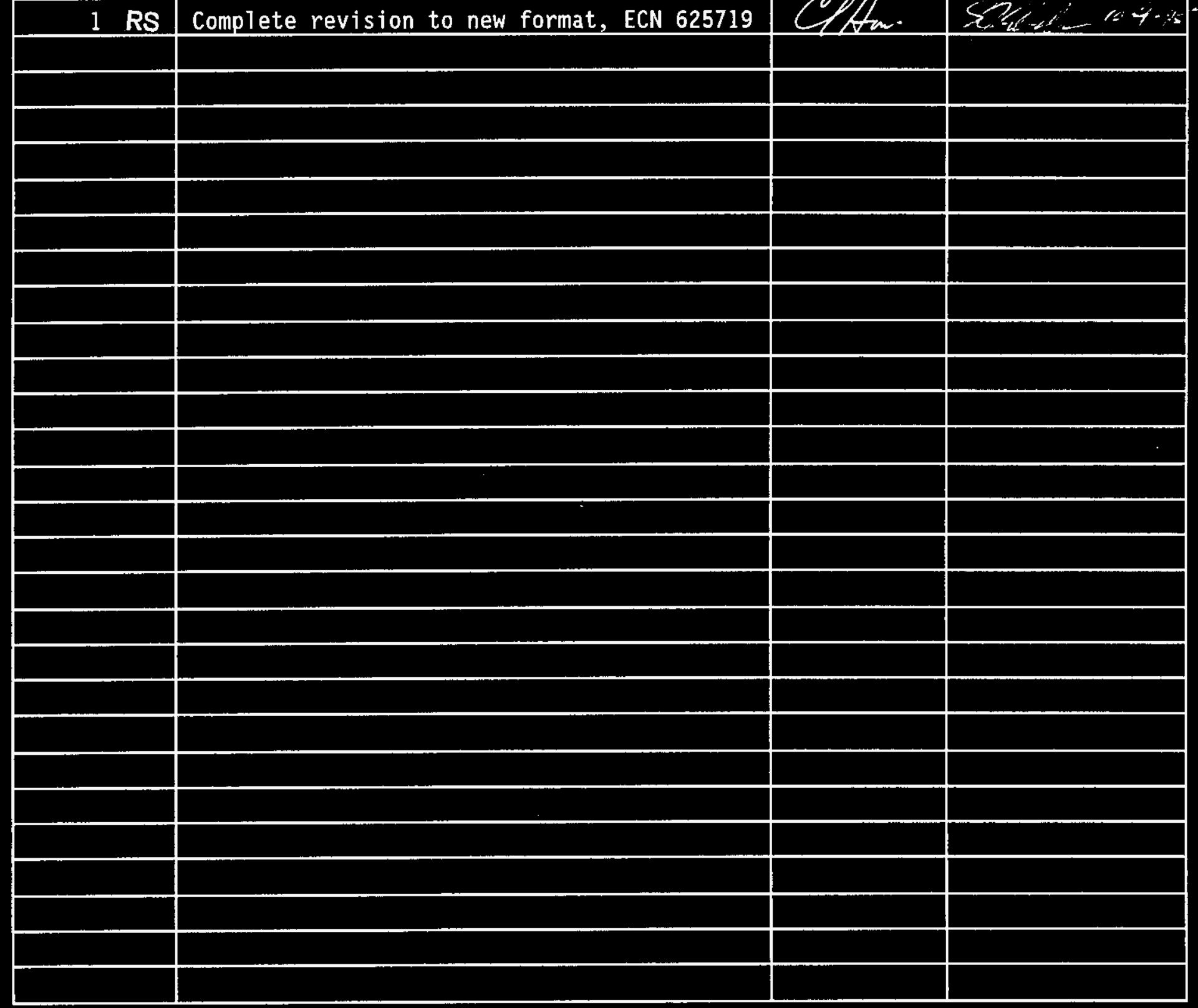




\title{
Tank 241-C-204 Tank Characterization Plan
}

\author{
C. S. Homi \\ Westinghouse Hanford Company
}

\section{Date Published \\ October 1995.}

Prepared for the U.S. Department of Energy Office of Environmental Restoration and

Waste Management

(2) Westinghouse $\begin{array}{ll}\text { P.O Box } 1970 \\ \text { Hanford Company }\end{array}$

Management and Operations Contractor for the

U.S. Department of Energy under Contract DE.AC06-87fiL10930 


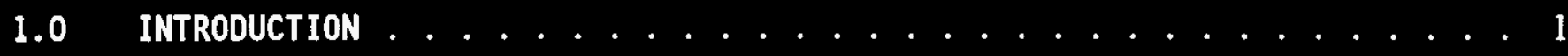

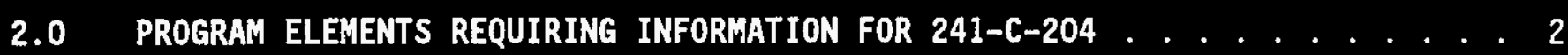

2.1 GENERAL SAFETY ISSUES . . . . . . . . . . . . . . 2

2.2 SPECIFIC SAFETY ISSUES . . . . . . . . . . . . . 2

2.2.1 Ferrocyanide ............... 2

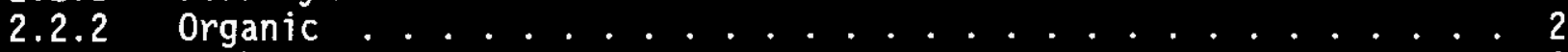

2.2 .3 High Heat ................ 2

2.2 .4 Flammable Gas ................. 2

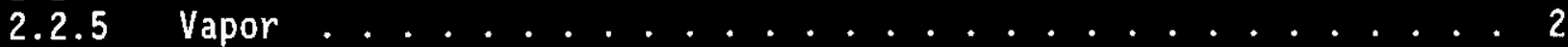

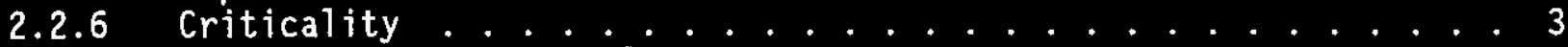

2.2.7 Screening Approach Evaluation ........... 3



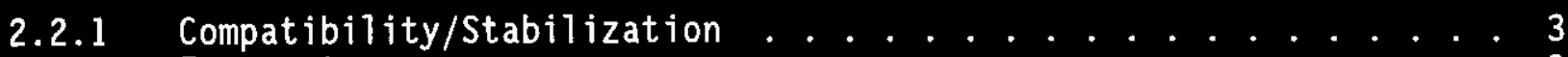

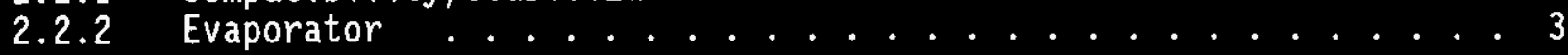

2.4 DOUBLE-SHELL TANK WASTE ANALYSIS PLAN . . . . . . . . . 3

2.5 DISPOSAL ...................... 3

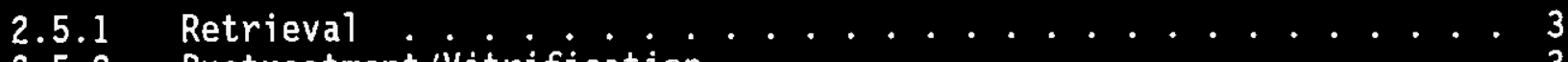

2.5.2 Pretreatment/Vitrification ........... 3

2.6 HISTORICAL MODEL EVALUATION . . . . . . . . . . . 3

3.0 HOK INFORMATION WILL BE OBTAINED ............... 4

4.0 PRIORITY OF INFORMATION REQUIREMENTS ............. 5

5.0 WHEN INFORMATION IS NEEDED ............... 5

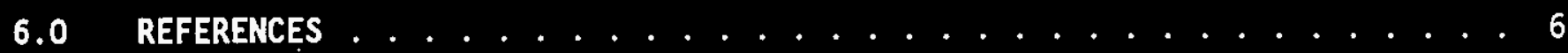

\section{LIST OF TABLES}

Table 4-1: Integrated DQO Requirements ............. 5 
WHC-SD-WH-TP-307, REV 1

\section{LIST OF ABBREVIATIONS}

C-204 Tank 241-C-204

DQO Data Quality Objective

HTCE Historical Tank Content Estimate

DSSF Double Shell Slurry Feed

NCPLX Non-complexed

SST Single-Shell Tank

TCP Tank Characterization Plan

SUMMA ${ }^{\circledR}$ Trademark of Molectrics, Inc.

TOC

USQ Total Organic Carbon

Unreviewed Safety Question

WHC Westinghouse Hanford Company 
WHC-SD-WM-TP-307, REV 1

\subsection{INTRODUCTION}

This Tank Characterization Plan (TCP) identifies the information needed to address relevant issues concerning short-term and long-term safe storage and long-term management of Single-She11 Tank 241-C-204 (C-204). It should be understood that the various needs and issues surrounding tank $C-204$ are evolving as new information about the tank is uncovered. As a result of this progression, this Tank Characterization Plan addresses only the issues that, to this date, have been identified. It is expected that deviations from this pian may occur as additional issues or needs arise which impact the management of SST C-204. As necessary, this Tank Characterization Plan will be revised to reflect those changes or deviations.

Tank C-204 was constructed between 1943 and 1944 and was put into service in January 1948. Initially tank C-204 received metal waste in January 1948 but, by the end of January 1948 the tank was full. During the fourth quarter of 1953, C-204 was sluiced to recover uranium and the supernatant was transferred to $c-106$. From the first quarter of 1954 until the third quarter of 1954, C-204 contained water and the remaining sludge. Again, C-204 was sluiced for uranium recovery in November 1954 and January 1955. After the completion of the January 1955 sluicing operation the tank was empty. From the fourth quarter of 1955 to the second quarter of 1976, C-204 contained semiworks waste. Presently, the tank waste is classified as non-complexed. This tank currently contains a total waste volume of $11.4 \mathrm{~kL}$ ( $3 \mathrm{kgal}$ ), which is equivalent to 46.5 centimeters ( 18.3 inches) of waste as measured from the basel ine of the tank. The waste is comprised entirely of sludge with no pumpable liquid remaining (Brevick 1994a).

The tank is categorized as an assumed leaker (with a leak volume of $1,325 \mathrm{~L}$ [350 gal] in 1988) and was declared inactive in 1977. Tank C-204 is passively ventilated and was interim stabilized in September 1982 with intrusion prevention completed in 1982. The last photo was taken on December 9, 1986. The 1989 photographic montage indicates a thin gray to saltcake surface layer that is "cracked" in which supernate can be seen (Brevick 1994b). The last solids volume update was obtained on April 28, 1982 (Hanlon 1995).

A waste sample analyses were conducted on a C-204 waste sample in October 1975 . The sample was described as a pale yellow 1 iquid that contained less than $1 \%$ solids. A cooling curve test was conducted on the sample and no further solids precipitated at any temperature.

This tank is not on a Watch List. Near-term sampling and analysis activities are focused on either verification of the non-watchlist tank status, identification of any new safety issues or changing the non-Watch List status. Should any safety issues be identified additional analysis will occur consistent with the identified issue.

In addition to the resolution of the safety issues, it is intended that all tank waste will be subject to pretreatment and retrieval to prepare for final storage or disposal. Presently, these long-range plans have yet to be fully identified and are, therefore, not included in this document. 
WHC-SD-WM-TP-307, REV 1

\subsection{PROGRAM ELEMENTS REQUIRING INFORMATION FOR TANK 241-C-204}

This section identifies the various program elements, and identifies which of these programs require characterization data from tank C-204.

\subsection{GENERAL SAFETY ISSUES}

The Tank Safety Screening Data Quality Objective (Babad et al. 1995) describes the sampling and analytical requirements that are used to screen waste tanks for unidentified safety issues. The primary analytical requirements for the safety screening of a tank are energetics, total alpha activity, moisture content, and flammable gas concentration.

\subsection{SPECIFIC SAFETY ISSUES}

\subsubsection{Ferrocyanide}

This tank is not on the Ferrocyanide Watch List and; therefore, no information needs are currently identified for this program element.

\subsubsection{Organic}

Tank C-204 is not on the Organics Watch List and; therefore, no information needs are currently identified for this program element.

\subsubsection{High Heat}

This tank is not on the High Heat Watch List and; therefore, no information needs are currently identified for this program element.

\subsubsection{Flammable Gas}

This tank is not on the Flammable Gas Watch List and; therefore, no information needs are currently identified for this program element.

\subsubsection{Vapor}

The tanks currently scheduled to be vapor sampled may be classified into four categories: (1) those tanks which are to be rotary mode core sampled (as a consequence of the rotary sampling system); (2) tanks on the Organic or Ferrocyanide Watch Lists; (3) tanks in C farm; and (4) tank BX-104, due to vapor exposure. Since tank $\mathrm{C}-204$ is categorized in one of the above four groups, information needs must satisfy Data Quality Objectives for Generic In-Tank Health and Safety Vapor Issue Resolution (Osborne et a1. 1995). Characterization of the tank headspace is needed to: 1) ident ify those tanks which can be sampled safely with intrusive equipment without risk of gas ignition; 2) identify and estimate concentrations of toxicologically significant compounds present in the tank headspace to establ ish worker safety precautions; and 3 ) support the startup and operation of the portable exhauster used during rotary-mode core sampling.

\subsubsection{Criticality}

No information separate from that for the general safety issue of tank C-204 are currently identified for this program element. However, if the general safety screening of tank $\mathrm{C}-204$ identifies a potential criticality concern, analyses for 


\section{WHC-SD-WM-TP-307, REV 1}

fissile materials and neutron absorbers and poisons will be performed as identified in the safety screening data quality objective.

\subsubsection{Screening Approach Evaluation}

The safety screening approach is currently under review. Information is required from key tanks to determine if a revised approach to screening may be adopted, as proposed in Meacham, 1995.

\subsection{CONT INUING OPERATIONS}

\subsubsection{Compatibility/Stabilization}

No information needs are currently identified for this program element.

\subsubsection{Evaporator}

No information needs are currently identified for this program element.

\subsection{DOUBLE-SHELL TANK WASTE ANALYSIS PLAN}

This section does not apply because tank $\mathrm{C}-204$ is a single shell tank.

\subsection{DISPOSAL}

\subsubsection{Retrieval}

Current retrieval needs (Bloom 1995) do not call for test samples to be taken from tank $\mathrm{C}-204$.

\subsubsection{Pretreatment/Vitrification}

Tank C-204 has not been identified as a bounding tank for pretreatment/disposal process development (Kupfer 1995).

\subsection{HISTORICAL MODEL EVALUATION}

Bounding tanks and data requirements for historical model evaluations are found in DQO Historical Model Evaluation Data Requirements (Simpson 1995). Tank C-204 has not been identified as a primary bounding tank for the MW (metal waste) waste type. 


\subsection{HOW INFORMATION WILL BE OBTAINED}

The safety screening DQO requires that a vertical profile of the tank waste be obtained from at least two widely spaced risers. This vertical profile may be obtained using core, auger (for shallow tanks), or grab samples. Vapor sampling and auger sampling events are required. The vapor sampling has not been scheduled at this time. The auger sampling type has been chosen over other sampling modes due to both the depth of the tank ( $\mathrm{C}-204$ is a shallow tank making rotary core sampling unnecessary) and the fact that the surface of tank $\mathrm{C}-204$ is comprised of saltcake.

The best current estimate of the water content in tank C-204 solids, as determined from the process records, is $57.4 \%$; based on the HTCE (Brevick et al). Est imated (Toth et al 1995) water content in tank $\mathrm{C}-204$ sludge is $59.8 \%$ (generated from a model based on sample data from similar tanks). If the variance of water in tanks already sampled and a statistical power curve is used then a minimum of two cores are needed to demonstrate a water content above $17 \%$ at $95 \%$ confidence. Should the measured mean be lower than anticipated or the measured variance higher, additional samples may be required. The TOC contained within the sludge is estimated (Toth et al 1995) to be $0.2 \%$ (wet basis), which is significantly lower than the level of concern. Two core samples will be requested for this tank and this should meet the requirements for the above parameters.

Presently, there is no information on the availability of tank $\mathrm{C}-204$ risers. It is recommended that risers be chosen that are separated radially to the maximum extent possible and; therefore, will provide a larger amount of data about the vertical and horizontal waste layers within the tank. Initial information will be taken from 3 risers and assessed to determine if more samples are required. Alternate sampling methods, installation of a riser or removal of equipment from risers are possible future options. 
WHC-SD-WM-TP-307, REV 1

\subsection{PRIORITY OF INFORMATION REQUIREMENTS}

Vapor sampling is scheduled for March 1996. Auger sampling was completed in May 1995 (Stanton 1995).

Tabie 4-1: Integrated DQO Requirements

\begin{tabular}{|c|c|c|c|}
\hline Sampling & Appl tcable DQO & Sampling Requirements & Analytical Requirements \\
\hline $\begin{array}{l}\text { Vapor } \\
\text { Sampling }\end{array}$ & $\begin{array}{l}\text {-Health \& Safety Vapor } \\
\text { Issue Resolution DQO }\end{array}$ & $\begin{array}{l}3 \text { SUMMA }{ }^{\circledR} \text { canisters } \\
6 \text { Triple Sorbent Traps } \\
8 \text { Sorbent Trap Systems }\end{array}$ & $\begin{array}{l}\text { Gas Flammability } \\
\text { Gas Toxicity } \\
\text {-Organic Vapors } \\
\text {-Permanent Gases }\end{array}$ \\
\hline $\begin{array}{l}\text { Auger } \\
\text { Sampling }\end{array}$ & $\begin{array}{l}\text {-Safety Screening } \mathrm{DQO} \\
\text {-Historical Mode1 DQO }\end{array}$ & $\begin{array}{l}\text { Core samples from } 2 \\
\text { risers separated } \\
\text { radially to the maximum } \\
\text { extent possible }\end{array}$ & $\begin{array}{l}\text { Energetics, Moisture, } \\
\text { Total Alpha, SpG, } \\
\text { Cations, Anions; } \\
\text { Radionuclides }\end{array}$ \\
\hline
\end{tabular}

\subsection{WHEN INFORMATION IS NEEDED}

Data are required for Tank C-204 during FY 1996 for safety screening and to prepare a Tank Characterization Report. 


\section{WHC-SD-WM-TP-307, REV 1}

\subsection{REFERENCES}

Babad, H, K. S. Redus, and J. W. Hunt, 1995, Tank Safety Screening Data Quality Objective, WHC-SD-WM-SP-004, Rev 1, Westinghouse Hanford Company, Richland, Washington.

Bloom, G. R., and Q. H. Nguyen, 1995, Characterization Data Needs for Development, Design, and Operation of Retrieval Equipment Developed Through the Data Quality Objective Process, WHC-SD-WM-DQ0-008, Rev. 0, Westinghouse Hanford Company, Richl and, Washington.

Brevick, C. H., 1994a, Historical Tank Content Estimate for the Northeast Quadrant of the Hanford 200 East Areas, WHC-SD-WM-ER-349, Rev. 0a, ICF Kaiser Hanford Company, Richland, Washington.

Brevick, C. H., 1994b, Supporting Document for the Historical Tank Content Estimate for BY Tank Farm, WHC-SD-WM-ER-312, Rev. O, ICF Kaiser Hanford Company, Richland, Washington.

Brown, T. M., S. J. Eberlein, D. A. Dodd, T. J. Kunthara, B. C. Simpson, and N. W. Kirch, Tank Waste Characterization Plan and Basis, 1995, WHC-SD-WM-TA-164, Rev 0, Westinghouse Hanford Company, Richland, Washington.

Fowler, K.D., 1995, Data Quality Objectives for the Waste Compatibility Program, WHC-SD-WM-DQ0-001, Rev. 1, Apri1 1995, Westinghouse Hanford Company, Rich1 and, Washington.

Hanlon, B.M., 1995, Waste Tank Summary for Month Ending May, 1995, WHC-EP-0182-82, Westinghouse Hanford Company, Richland, Washington.

Homi, C. S., and S. J. Eberlein, 1995, Fiscal Year 1996 Tank Waste Remediation System Tank Waste Analysis Plan, WHC-SD-WM-PLN-101, Rev 0, Westinghouse Hanford Company, Richland, Washington

Kupfer, M. J., W. W. Schultz, and J. T. Slankas, 1995, Strategy for Sampling Hanford Site Tank Wastes for Development of Disposal Technology, WHC-SD-WM-TA-154, Rev. 1, Westinghouse Hanford Company, Richland, Washington.

Meacham, J. E., R. J. Cash, B. A. Pulsipher, and G. Chen, 1995, Data Requirements for the Ferrocyanide Safety Issue Developed through the Data Quality Objectives Process, WHC-SD-WM-DQ0-007, Rev. 1, West inghouse Hanford Company, Richland, Washington.

Osborne, J.W., J.L. Huckaby, E.R. Hewitt, C.M. Anderson, D.D. Mahlum, B.A. Pulsipher, and J.Y. Young, 1995, Data Quality Objectives for Generic In-Tank Health and Safety Vapor Issue Resolution, WHC-SD-WM-DQ0-002, Rev. 1, Westinghouse Hanford Company, Richland, Washington.

Price, D. N., 1994, Rotary Core Vapor Sampling Data Quality Objective, WHC-SD-WM-SP-003, Rev. 0, Westinghouse Hanford Company, Richland, Washington.

Simpson, B. C., and D. J. McCain, 1995, Historical Model Evaluation Data Requirements, WHC-SD-WM-DQO-018, Rev. 0, West inghouse Hanford Company, Richland, Washington. 
WHC-SD-WM-TP-307, REV 1

Stanton, G. A., 1995, Baseline Sampling Schedule, Revision 4.3, (internal memo 74320-95-04, to distribution, March 24), Westinghouse Hanford Company, Richland, Washington.

Toth, J. J., P. G. Heasler, M. E. Lerchen, J. G. Hi11, and P. D. Whitney, 1995, Analysis of Organic Carbon and Moisture in Hanford Single-Shell Tank Waste, PNL10360, Pacific Northwest Laboratory, Richland, Washington. 